\title{
The Effects of Capital Market Development and Foreign Direct Investment on the Entrepreneurial Process and Economic Growth
}

\author{
Tékam Oumbé Honoré ${ }^{1, *}$ \\ ${ }^{1}$ Faculty of Economics and Management, University of Dschang, Dschang, Cameroon \\ *Correspondence: Faculty of Economics and Management, University of Dschang, Dschang, \\ Cameroon. E-mail: h_tekam@yahoo.fr
}

Received: October 2, 2018 Accepted: November 14, 2018 Published: December 18, 2018 doi: 10.5296/rae.v10i4.14077ＵRL: https://doi.org/10.5296/rae.v10i4.14077

\begin{abstract}
This article seeks to study the effects of the development of the capital market and foreign direct investment (FDI) in the entrepreneurial process and economic growth. The technical methods used in this study are the panel-based dynamic estimation method of the Generalized Method of Moments (GMM) and the Calderon-Rossell model, in order to assess the relative impact of the development of capital markets on the entrepreneurial process in the CEMAC zone. The results show that capital market and capitalization initiatives can lead to an entrepreneurial process and economic growth in the CEMAC region. In addition, the incidence of corruption, the rule of law and the quality of the regulatory framework are identified as the most important institutional frameworks that determine the attractiveness of CEMAC countries to the inflow of FDI.
\end{abstract}

Keywords: Capital Market Development, Foreign Direct Investment, Entrepreneurial Process, Economic Growth, CEMAC 


\section{Introduction}

Capital markets are a virtual or physical place for the exchange of long-term financial securities, including shares, long-term debt securities such as debentures, unsecured debt and convertible bonds. In addition, government bonds and other public sector securities such as treasury bills and sharp stocks, are also traded on the capital markets. In fact, the structure of a global capital market has three components: the first component is the primary capital market for new capital issues by firms and other institutions, including governments; the second is the secondary market, for the exchange of existing securities; and the third is the derivatives market, which is used to exchange securities created through exchange and whose value comes from the underlying securities.

It can therefore be argued that by functional classification, capital markets play three main roles. Firstly, companies that want to invest, such as financial institutions and private investors, can raise long-term funds. By fulfilling this role, they act as primary markets for new equity and debt issues. Secondly, financial markets offer investors a convenient way to sell stocks and bonds they own or buy others to increase their portfolio. In fulfilling this role, capital markets act as secondary markets for the trading of existing securities. Thirdly, the markets provide for future and potential debt swaps based on the value of the underlying assets; hence the derivatives market.

However, at the global level, the evolution of emerging capital markets over the past two decades has been dichotomous; that is to say, the markets have experienced both integration and segmentation. On the one hand, some emerging capital markets have experienced a remarkable increase in foreign direct investment and an entrepreneurial process due to the expansion of privatization, the use of bond instruments in international debt settlements and successful implementation of economic stabilization programs. Thus, foreign capital inflows into mature capital markets have allowed these markets to better integrate into global markets. On the other hand, some very small, less developed capital markets, defined as "frontier markets" by Standard \& Poor's International Finance / Emerging Markets database, have not received much of foreign capital.

Markets have therefore become segmented into global markets. Consequently, dichotomous integration and segmentation patterns have important consequences for the role played by these markets in emerging economies, particularly in Africa and the CEMAC zone. Foreign direct investment (FDI) refers to an international investment in which the investor acquires a lasting interest in a business in another country. The entrepreneurial process involves all the functions, activities and actions associated with the perception of opportunities and the creation of organizations to exploit them. Economic growth is typically measured by the percentage increase in real gross domestic product (GDP), usually expressed per capita.

To support this trend, the IMF noted in 2007 that the capitalization of African stock markets more than doubled between 1992 and 2006, rising from 113 billion USD to 245 billion USD. Today, there are 29 stock exchanges in Africa, representing the capital markets of 38 countries, 21 of which are members of the African Stock Exchange Association (ASEA). In 
fact, the recent increase in foreign investment flows and the development of capital markets in sub-Saharan Africa in general and in the CEMAC zone in particular; are clear indications of the evolution of the world economic order. To this end, the general question for this study is: how can capital market development and the influx of FDI strengthen the business process and strengthen the economic growth of the CEMAC region? This article aims to analyze the relationship between capital market development and FDI inflows in the entrepreneurial process and the economic growth of the CEMAC zone. This article is organized as follows: in section 2, we do an analysis of the related literature; Section 3 presents the methodology, the econometric model and the data sources. Section 4 presents the empirical results and section 5 concludes.

\section{Literature Review}

African stock markets are easily and potentially transforming the economic fortunes of sub-Saharan African countries with the presence of a robust and dynamic securities market that has a positive impact on society and serves as a powerful engine for promoting growth and development. With this in mind, (Levine \& Zervos, 1996) have argued that global equity markets are booming, with equity markets in developing countries accounting for a disproportionate share of this growth; this allows investors to venture into these new global markets, some already showing good returns. But the question that has been asked is whether developing countries themselves derive benefits from their stock markets. Moreover, King and Levine (1993) have focused their efforts on the role of financial development in economic growth and country development. Overall, there is an overwhelming consensus that successful financial intermediaries have played an important role in economic growth.

Thus, the development of the capital market is considered crucial for attracting foreign direct investment (FDI). In addition, capital market development which aims to improve the functioning, efficiency and relevance of the capital market system plays a key role in generating surplus funds and channelling them to deficit units of the economy through market agents (Madura, 2001). More fundamentally, a developed capital market serves as a channel through which foreign capital enters an economy and is also an indication of the viability of the market to absorb structural financial shocks. Apparently, after the initial capital commitment of multinational enterprises; Multinational companies (MNCs) expect that subsequent long-term investments will come from the domestic capital market to improve the operational sustainability of multinationals in the host country (Caves, 2007). Thus, a well-developed capital market indicates to foreign investors that complementary domestic capital is available to leverage new investments and diversify portfolio risks (Jeffus, 2004).

A more developed equity market also provides liquidity that reduces the cost of foreign capital essential for development. As such, the presence of stock markets would alleviate the problem of prime agents and reduce asymmetry, thus promoting an efficient allocation of resources and growth, highlighting the fact that diversified ownership is an essential element of political stability which favors growth (Adjasi \& Biekpe, 2006). However, it has also been argued that stock markets may be counterproductive; for example, more liquid stock markets 
may expose companies to counterproductive takeovers, or even to high integration and technology development, if a stock market is not controlled, it can lead to economic collapse. In addition, the effect of uncertainty on the savings rate and economic growth as markets become more liquid is hazy (Bencivenga \& Smith, 1991). Levine and Zervos (1996) find a strong positive correlation between stock market development and economic growth. However, there are authors who have not been able to establish a significant link between the development of stock markets and growth, such as Bencivenga and Smith (1991), Naceur and Ghazouani (2007) and Adjasi and Biekpe (2006) who focus on developing countries.

Globally, the development and stability of the capital market is considered the most essential for the destination of FDI. Although FDI is more resilient to financial market crises than foreign portfolio investment (Arias \& Hausman, 2001), it is less easily reversible than other forms of capital inflows (such as Short-term and long-term portfolio investments (term loans, foreign currency deposits and other accounts receivable) allude to the cautious premonition of foreign investors (Ito, 1999; Madura, 2001; Gullapalli, 2013). Despite concerted efforts to attract foreign direct investment from African countries, investors are largely reluctant to engage in long-term production activities in Africa, particularly in the form of upstream investments.

In addition, the liberalization and privatization process imposed by the Bretton Woods institutions in the late 1980s has been a dominant factor in the development strategies of less developed countries (LDCs). Governments have therefore developed new attitudes towards the role that the private sector could play in development. This contrasted sharply with the purely dominant notion of the corporate function of the state. As a result, entrepreneurship has received increasing attention. The innovative dimension of entrepreneurship is the basis of the entrepreneurial process, characterized by knowledge (market, product and process).

For some authors, entrepreneurship influences economic growth and development (Kersan-Skabic, 2004; Ajagbawa, 2014; Oke \& Jolaosho, 2014; Vullo and al., 2017).

Herbert and Link (1989) distinguished two categories of entrepreneurs. The first concerns static theories, in which the entrepreneur is considered as a passive figure, whose actions are simple repetitions of procedures or techniques already acquired and implemented. In dynamic theories, the entrepreneur plays an important and active role and continues to improve throughout his life.

According to (Krueger, 2003) over the last twenty years, the literature on the intention of entrepreneurship has produced different models. Many researchers have identified risk propensity as one of the distinguishing features of the entrepreneurial figure, defining it as the ability to pursue the realization of their own entrepreneurial idea, regardless of the conditions of uncertainty and low probability of entrepreneurship success. In the entrepreneurial personality, they also recognise two relevant factors: risk-taking, namely the ability to withstand a certain degree of risk, and the measure of risk, namely the ability to measure the unpredictability of the business situation.

Stewart and Roth (2001) find that entrepreneurs need a natural risk propensity for their work. 
According to Moore's model, (Bygrave, 2004) presents the business process as a set of successive stages and events. These steps are: the idea or design of the business, the event that triggers the operations, the implementation and growth. In his entrepreneurial process model (see figure below), (Bygrave, 2004) highlights the critical factors that determine business development at each stage. According to him, as with most human behaviors, the characteristics of the business are shaped by personal attributes and the environment.

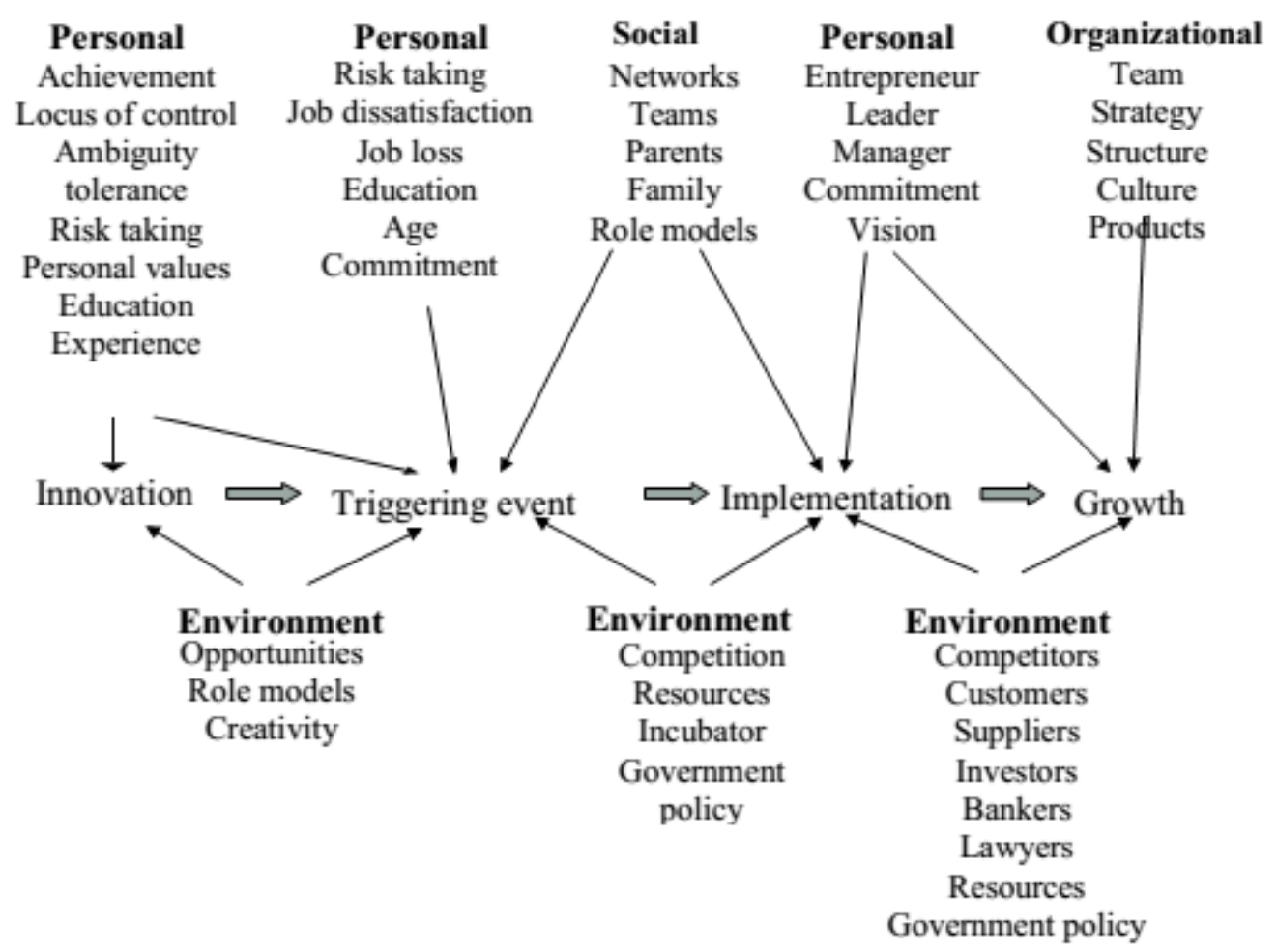

Figure 1. A model of Entrepreneurial Process

Source: Author based on Bygrave (2004) and Carol Moore's model.

In seeking to contribute to the identification and understanding of the behavior likely to lead an entrepreneur to success, (McClelland,1965) identifies the following entrepreneurial characteristics: search for opportunities and initiative, identification of opportunities, ability to react to frustration and stress situations, quality and effectiveness requirements, commitment, goal setting, systematic planning and monitoring, persuasion and network of contacts, and independence. Timmons (1978) agrees that some personal attributes, such as the need for achievement, the propensity to take calculated risks and the locus of control (intense desire to control one's own destiny), are observed in the majority of successful entrepreneurs.

Filion (1999) states that the literature often indicates that entrepreneurs are actively striving to achieve their goals and developing tenacity and creativity, as well as their ability to detect opportunities and as agents of change, that is to say, and different things. Thus, Ozaralli and 
Rivenburgh (2016) have recently introduced the concept of "entrepreneurial culture", defining it as the set of interpersonal and contextual factors that enable and favor entrepreneurial activities the most. These cultural dimensions, in detail, assume different roles depending on the specific environment or the different importance they have in different cultures.

Nassif et al. (2010) propose the dynamic framework of the entrepreneurial process to understand the skills of the entrepreneur from a perspective that categorizes the characteristics of the entrepreneur. They distinguish two aspects of the business process: cognitive aspects that incorporate: calculated risk taking, ability to partner, goal setting, skill planning, knowledge of boundaries, and communication with eloquence. The emotional aspects of the business process dynamics framework include perseverance, courage, self-reliance, self-confidence, independence, willingness to take risks, personal motivation, solving challenges, passion for business and respect for tastes.

The entrepreneurial process is a key factor in promoting economic growth. Entrepreneurs need a vital element such as the development of the capital market to attract FDI inflows and contribute to the growth of the country's financial sector. In turn, this means improving private sector access to services such as bank credit, equity, and payment and risk management services (Rwelamira, 1993). In addition, the development of the financial sector follows a trend starting with the channeling of savings and investment through banks, and then the gradual development of capital markets as savers for higher returns. In fact, financial markets typically include several institutions, including banks, insurance companies, mutual funds and pension funds, as well as stock and bond markets.

In this regard, the development of capital markets in Africa is an increasingly interesting area of research, particularly in the context of CEMAC. In fact, in recent decades, there has been a dramatic increase in the number of stock markets and improved capitalization, as well as increased bank efficiency on the continent. To this extent, African capital markets are progressively seen as viable and capable of supporting a significant level of real economic activity. For example, a number of African countries such as Ghana, Malawi, Swaziland, Uganda and Zambia, among other developing countries, have established stock markets in order to remain competitive in the global capital market. (Gullapalli, 2013). In addition, between 1989 and 2007, the number of domestic stock markets in Africa increased from nine to 16 (Africa Stock Exchange Association, 2013).

In recent decades, entrepreneurship has become a popular subject for academics and policy makers because of its special role in the economic and social development of countries. It is able to cope with the current economic crisis by stimulating innovation and technological progress, creating competition, creating jobs and encouraging economic growth in general. The objectives of this article are to provide a systematic review of the main theoretical approaches gradually introduced over the years and to analyze the different determinants of entrepreneurial behavior. By describing the personal, social and societal factors, we maintain that it is necessary to develop the analysis and studies on this subject, including from a psychological perspective, in order to plan training programs that are useful both for the sake 
of the individual and for that of the society to develop.

Corbett and Jenkinson (1994) find that the contribution of equity markets to the financing of business investment is negative in the United Kingdom but slightly positive in the United States during the 1970s and 1980s. In addition, in two other studies (Akyuz, 1993) and Singh (1997) find that adverse economic shocks resulting from the interaction between stock markets and foreign exchange markets lead to macroeconomic instability, which in turn has a negative impact on economic growth. In fact, given the mixed empirical evidence on the link between stock market development and economic growth, this review attempts to examine the existing literature on the conditions that hinder the development of financial markets in sub-Saharan Africa (SSA) in general and in the CEMAC zone in particular.

Although portfolio investment is an important component of the stock of foreign capital inflows, the simple fact that they are easily reversible prevents them from accepting the long-term investments necessary for sustainable growth of the economy, relative to capital with a long-term commitment in the form of FDI. This suggests that foreign direct investment is preferred over foreign portfolio investment in most developing countries (Meyer, 2004). In addition, the realization that the national economy is not sustainable enough to generate the funds needed to grow the economy to reduce the level of poverty reinforces the strategic interventions of African leaders. For decades, African leaders have consistently pursued regulatory reforms to attract more foreign capital, particularly in the form of FDI. However, this effort has not yielded the expected results, mainly due to the weak development of local capital markets relative to other developing countries (Chousa et al., 2008; Hailu, 2010), and the institutional inadequacy. In fact, after having committed the initial capital in the creation of a subsidiary abroad, the multinationals would prefer an offshore site sufficiently viable to mobilize the funds necessary for the durability of the subsidiary and its future expansion (Meyer, 2004).

FDI is a development tool because it provides the capital that these countries need directly. There is a need to increase investment and competition in host-country industries while improving the productivity of local firms through the adoption of more efficient technologies or investment in human and/or physical capital. FDI also improves the management capacity of local businesses (Bellon \& Gouia, 1998). In fact, by way of illustration, FDI inflows account for more than $50 \%$ of GDP in some countries in the CEMAC region. FDI has many benefits, including: it is in particular a source of physical and human capital, creates jobs and gives access to foreign markets (Onwuka \& Chicozie, 2014). Its impact on local businesses is positive in terms of technology and efficiency. Given that FDI provides access to foreign markets, technology exchanges generally create skills in firms in host countries. However, they can only improve the integration of these countries into the world economy while promoting economic growth. The main focus of developing country leaders on FDI is the search for additional funds, as they generally do not have sufficient financial resources (Maingy, 2004). This table summarizes the determinants of FDI inflows into the business process. 
Table 1. Summary of Key Empirical Literature on the Determinants of the Direction of FDI Flow

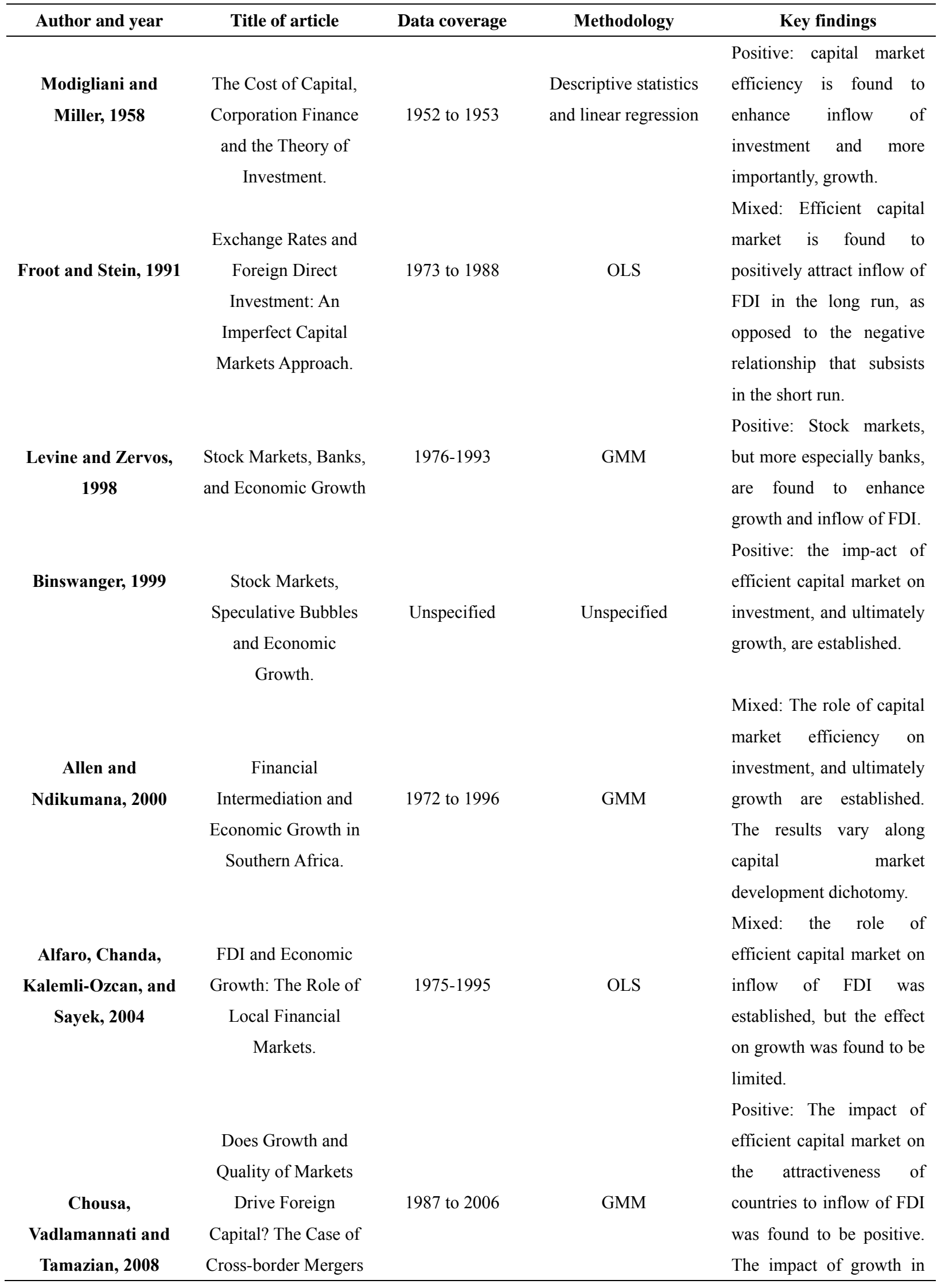


and Acquisitions from

leading Emerging

Economies.

Adam and

Foreign Direct

$1991: 1-2006: 4$

Investment and Stock

Tweneboah (2009)

Market Development:

Ghana's Evidence

Barna and Mura

(2010)

Capital Market

Development And

Economic Growth:

The Case Of Romania

Multinationals as

Baker, Foley and

Wurgler, 2009

and Irena, 2013

Emmanuel and King

(2014)

Akinmulegun S.

(2018)

2000:1-2009:4

this regards is also found

to be significant.

VECM

The stock of FDI

influences the

development of the dung beetle in Ghana.

OLS

The development of the

capital market is

positively correlated with

economic growth.

Positive: The impact of efficient stock market on the attractiveness of

1975 to $2001 \quad$ GMM

countries to inflow of FDI was found to be

significant.

Mixed: the relationship between efficient stock

Capital Market

Development and

Foreign Portfolio

Investment Inflow in

Nigeria (1985-2016)

VAR and Cointegration Analysis

Croatia: Evidence

from VAR and

Cointegration

Analysis.

Effect of capital

market development

on economic growth

$$
\text { in Ghana }
$$

1980 to2015

financial development

on foreign direct

investment in Nigeria

1991:1-2011:4

\section{Layered Regression \\ Technique}

VECM

1985 to 2016

Granger causality test

between the development of capital markets and

foreign portfolio investment in Nigeria. 


\section{Methodology}

The current global economic and financial crisis poses major challenges to FDI. The challenge is even greater in Central African countries where the workforce is less skilled. Developing countries in need of skilled labor have the advantage of attracting more FDI. The success of business processes would likely depend on their ability to acquire management skills, to understand and adapt to international markets. In addition, FDI faces the challenge of adapting to management styles, especially in emerging countries with less time to develop the necessary skills and competencies (Hanglund, 2008). Multinational enterprises in emerging countries have undertaken foreign direct investment (FDI). The bottom line is that these countries are less likely to have built the entrepreneurial process. Sometimes lack of leadership to sacrifice comfortable lifestyles in their home country for work abroad also threatens the success of FDI.

We start by examining the model used in the Chousa et al. (2008) study. In this study, the authors analyze the importance of capital market growth and development in determining the attractiveness of countries for inflows of FDI. However, the model used in this study focused more on debt than on the equity market, which makes the application of this model inappropriate in this study. Moreover, the models used in the work of (Jeffus, 2004), in which the relationship between stock market development and FDI inflows were estimated, are also taken into account in the linear equation to model this form of relationship.

However, some of the major weaknesses in these models are the possible endogeneity problems between economic liberalisation and FDI, as well as between stock market liquidity and transparency/disclosure that are combined together in the same equation. The model is given as follows:

$$
\log Y_{i t}=\alpha_{1}+\alpha_{2} C M I_{i t}+\alpha_{3} X_{i t}+\varepsilon_{i t}
$$

Thus, as indicated above in the model: $Y_{i t}$ is economic growth measured as the log of: $\left(G D P C_{t} / G D P C_{t-1}\right)$ in country $i$ and at time $t$. As observed and discussed earlier, the proxy for economic growth is averaged for a test of robustness in the growth model. $C M I_{i t}$ is the capital market indicator for country $i$ at time $t$; while $X_{i t}$ contains control variables and $\varepsilon_{i t}$ is the error term. Altogether, given that this study focusses on investigating the possible relationships between capital market development (CMI) and the inflow of FDI (FDI), there is the need to reconstruct the model of (Levine \& Zervos, 1996). The reconstructed basic model will substitute the inflow of FDI for growth while retaining the capital market component. The new model is presented in equation 2 below:

$$
F D I_{i t}=\alpha_{1}+\alpha_{2} C M I_{i t}+\alpha_{3} X_{i t}+\varepsilon_{i t}
$$

From the equation above, $F D I_{i t}$ represents inflow of FDI, while $C M I_{i t}$ is the capital market indicators. As in equation $1, X_{i t}$ contains the control variables while $e_{i t}$ is the error term. This novelty is considered essentially necessary given that stock market capitalisation and trading may have different pull effects on the inflow of FDI (Adjasi \& Biekpe, 2006; Baker et al., 2009). 
Evidently, data is not available for some of the variables identified above (such as strengthening the rule of law, improved regulatory mechanism, and better governance), thereby making them difficult to measure accurately. As such, the econometric equation takes a lead from Biekpe (2002) and applies the variables that are available on the databases used in this study. In fact, it must be pointed out that the model specified in equation 2 will be modified to suit the proposed objectives of this section of the study. Given that this section of the study focuses on investigating the possible relationships between capital market development (CMI) and institutional efficiency (INST), there is the need to remodel the equation presented in equation 2 above. In fact, in the remodelled basic equation, we substitute capital market variables for inflow of FDI. Furthermore, the institutional variables (INST) will be introduced as substitutes for capital market variables.

Five models will be specified to determine the relationship between capital market development and institutional efficiency, and each of the models will be capturing the relationship between the identified institutional variables and each of the five capital market variables (in this case, as the dependent variables). These model specifications are depicted in equations 3 to 7 . They satisfy the third research hypothesis and answer the third and fourth research questions.

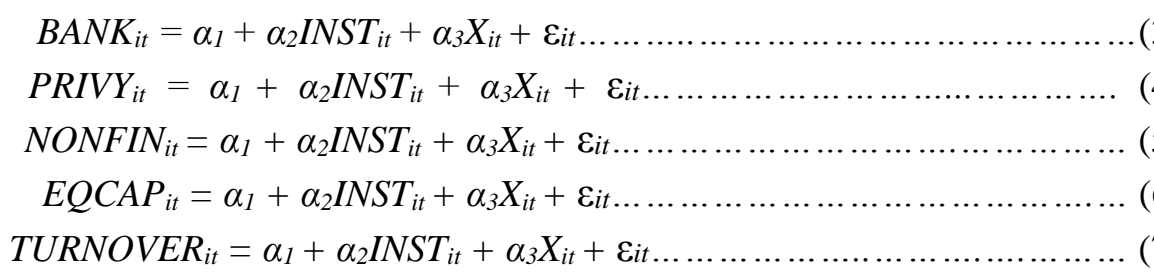

In equations 3 to 7, $C M I_{i t}$ captures the capital market indicators for country $i$ at time $t$. These variables are the same set of variables used in equation 2. INST proxies the institutional variables, while $\mathrm{X}_{\mathrm{it}}$ contains control variables and $\varepsilon_{i t}$ is the error term. In fact, from equations 3 to 7 , the five dependent variables are represented by the financial resources provided to the private sector by the domestic money banks as a percentage of GDP, which is depicted as $B A N K$. In addition, PRIVY depicts the domestic credit to the private sector as a share of GDP and includes entrepreneurial process. The other three dependent variables in this section include claims on domestic real non-financial sector by the Central Bank as a share of GDP (NONFIN) and the market capitalisation of listed companies, that is, the total value of all listed shares in a stock market as a percentage of GDP (EQCAP). The last dependent variable is the total value of all traded shares in a stock exchange market as a percentage of GDP, which is represented as TURNOVER. However, the independent variables (INST) include the rule of law ( $L A W R U L E)$, the combined polity score (POL. STAB.), which shows the political dynamics of the economy. Other variables include the annual percentage change in consumer prices (INFLA), the quality of legal system (QLEGAL), and the prevalence and depth of corruption that is measured through the corruption perception index (CORRUP). In fact, as observed in equations 3 to 7 , the control variables are introduced into the estimation. According to La Porta et al. (2000), the per capita income (GNI per capita at constant prices) plays a major controlling role in estimating the institutional dynamics of the capital market. For the sake of potential endogeneity, this variable will not be used in this study. Furthermore, 


\section{Macrothink

the control variable adopted by Bosworth et al. (1999), is considered unsuitable in this study, especially because our study concerns the CEMAC sub-region only. To that effect, the fixed effects technique will be applied in the estimation alongside sub-regional dummy effects. Also, the control variables such as the cost of enforcing a contract (ENFORCE), which is a proxy for the cost of seeking a contractual compensation after the a breach is be used as in the study of Rousseau, Wachtel (2000).

\section{Empirical Results}

The different means and standard deviation of the different variables of macroeconomic performance are presented in Table 2 below.

Table 2. Descriptive Statistics

\begin{tabular}{llllll}
\hline Variables & Mean & Standard Deviation. & Minimum & Maximum & Observation \\
\hline$Y_{t}$ & 6.49 & 11.69 & -8.93 & 71.18 & 102 \\
$I$ & 26.34 & 17.69 & 4.31 & 113.57 & 92 \\
$G$ & 9.53 & 5.81 & -8.97 & 24.19 & 94 \\
INFLA & 3.76 & 2.74 & -2.06 & 10.03 & 100 \\
INFRAS & 1.02 & 0.91 & 0.08 & 3.28 & 102 \\
CORRUP & -0.76 & 0.75 & -2.14 & 0.45 & 102 \\
POL. STAB. & -1.08 & 0.26 & -1.68 & -0.42 & 102 \\
\hline
\end{tabular}

Source: Author with Data from the World Bank and African Development Bank

From Table 2 above, the rate of economic growth in the CEMAC sub-region is $6.49 \%$ which is since two decades above the average for Africa which is $4.9 \%$. However, the countries of the region show many differences in their rates of growth. Thus, from 1996 to 2006, growth in the region was characterized by the evolution of primary produce which witnessed a dramatic increase in 2006.

A detail analysis of the differences in means of variables is presented in Table 3 below. From that table, we have the means and $p$-value in parentheses. It should be appreciated that all the explanatory variables portray an insignificant or weak difference in means. These variables have a $p$-value of less than $5 \%$, which shows therefore their significance. 
Table 3. Analysis of Difference of Means Dependant Variable: Economic Growth Rate: Y

\begin{tabular}{lllllll}
\hline Variables & Cameroon & Congo & Gabon & Eq. Guinea & Central Africa Rep. & Chad \\
\hline \multirow{4}{*}{ I } & 2.04 & 0.1225 & 0.514 & 2.3057 & 1.452 & 3.628 \\
$G$ & $(0.0039)$ & $(0.0052)$ & $(0.0000)$ & $(0.0048)$ & $(0.0002)$ & $(0.0003)$ \\
& 0.013 & 5.291 & 0.0307 & 2.8414 & 0.4521 & 1.508 \\
INFLA & $(0.0002)$ & $(0.0000)$ & $(0.0184)$ & $(0.0000)$ & $(0.2476)$ & $(0.0550)$ \\
& 9.709 & 10.441 & 9.38 & 7.9341 & 9.9508 & 10.0304 \\
INFRAS & $(0.0000)$ & $(0.0000)$ & $(0.0000)$ & $(0.0000)$ & $(0.0000)$ & $(0.0000)$ \\
& 9.782 & 10.439 & 9.456 & 7.8010 & 9.7721 & 9.7618 \\
CORRUP & $(0.0000)$ & $(0.0000)$ & $(0.0000)$ & $(0.0000)$ & $(0.0000)$ & $(0.0000)$ \\
& 7.196 & 11.584 & 8.2262 & 7.295 & 8.18 & 7.5362 \\
POL.STAB. & $(0.0000)$ & $(0.0278)$ & $(0.0000)$ & $(0.0012)$ & $(0.0000)$ & $(0.0023)$ \\
& 12.1941 & 11.0706 & 9.823 & 9.134 & 11.576 & 11.7990 \\
& $(0.0000)$ & $(0.0000)$ & $(0.0000)$ & $(0.0000)$ & $(0.0000)$ & $(0.0000)$ \\
\hline
\end{tabular}

Source: author with Data from the World Bank and African Development Bank

The difference of means between the GDP and household consumption on the one hand and government expenditure on the other hand are not significant. This situation is explained by the nature of the data. In general, the above results show a good behaviour of the explanatory variables, which confirms the results of the descriptive statistics. More so, a further analysis of the link between investment legislation with other variables and macroeconomic performance are presented in Table 4.

Table 4. Correlation Matrix of Dependent Variable and Independent Variables

\begin{tabular}{llllllll}
\hline & Y & G & INFLA & INFRAS & CORRUP & POL._STAB. & DUMMY \\
\hline$Y$ & 1 & & & & & & \\
$I$ & $0.5846^{*}$ & & & & & & \\
$G$ & $-0.156^{*}$ & 1 & & & & & \\
INFLA & 0.1765 & 0.3615 & 1 & & & & \\
INFRAS & $-0.034^{*}$ & $0.0742^{*}$ & -0.2415 & 1 & & & \\
CORRUP & $-0.165^{*}$ & 0.0303 & $-0.175^{*}$ & $0.7512^{*}$ & 1 & & \\
POL.STAB. & $-0.349^{*}$ & 0.3031 & -0.0647 & -0.0537 & $0.0012^{*}$ & 1 & \\
DUMMY & $1.234^{*}$ & $2.0145^{*}$ & 1.0562 & 0.3564 & 0.2756 & 0.0251 & 1 \\
\hline
\end{tabular}

Source: Author with Data from the World Bank and African Development Bank

* indicates significance at $5 \%$.

From the Table, the correlation matrix shows that all the explanatory variables are strongly correlated with the explained variable (Y) except inflation. The signs of the coefficients associated with the explanatory variables are in conformity to theory except in the cases of government expenditure, infrastructure and inflation where the correlation between the explanatory variables is weak and in most cases insignificant. In general, when the 
correlations are weak, that indicates the absence of multi-collinearity. However, an in-depth analysis is done in Table 5 which shows the estimates of the macroeconomic performance function.

Table 5. Results of Estimations

\begin{tabular}{|c|c|c|c|c|}
\hline Explanatory Variables & Model 1 & Model 2 & Model 3 & Model Global \\
\hline \multirow[t]{2}{*}{$Y_{t-1}$} & $1.21 * *$ & & & $1.62 *$ \\
\hline & $(0.15)$ & & & $(1.07)$ \\
\hline \multirow[t]{2}{*}{$I$} & $0.19 *$ & & & 1.02 \\
\hline & $(0.10)$ & & & $(1.01)$ \\
\hline \multirow[t]{2}{*}{$G$} & 0.287 & & & -0.62 \\
\hline & $(0.27)$ & & & $(1.35)$ \\
\hline \multirow[t]{2}{*}{$I N F L A$} & & -0.22 & & $-0.18^{*}$ \\
\hline & & $(0.468)$ & & $(0.67)$ \\
\hline \multirow[t]{2}{*}{ INFRAS } & & $-12.28 *$ & & $2.98 * *$ \\
\hline & & $(5.03)$ & & $(6.01)$ \\
\hline \multirow[t]{2}{*}{ CORRUP } & & $-1.40 * *$ & & $-1.25^{*}$ \\
\hline & & $(3.17)$ & & $(2.38)$ \\
\hline \multirow[t]{2}{*}{ POL_STAB } & & $-1.04 *$ & & $-1.78 *$ \\
\hline & & $(6.22)$ & & $(6.15)$ \\
\hline \multirow[t]{2}{*}{$D U M M Y$} & & & $1.99 * *$ & $2.35^{*}$ \\
\hline & & & $(2.50)$ & $(2.21)$ \\
\hline \multirow[t]{2}{*}{$D U M M Y^{*} I$} & & & $2.15^{*}$ & $1.98^{*}$ \\
\hline & & & $(1.24)$ & $(1.35)$ \\
\hline \multirow[t]{2}{*}{$D U M M Y^{*} G$} & & & $0.52 *$ & $0.61 * *$ \\
\hline & & & $(2.35)$ & $(1.58)$ \\
\hline \multirow[t]{2}{*}{ _Cons } & $2.01^{* * *}$ & $1.91 * *$ & $2.62 * *$ & $6.19 *$ \\
\hline & $(1.15)$ & $(2.17)$ & $(3.18)$ & $(4.12)$ \\
\hline Numbers of Obs. & 84 & 84 & 84 & 102 \\
\hline Prob $>F$ & 0.000 & 0.001 & 0.006 & 0.000 \\
\hline$R$-squared & 0.82 & 0.79 & 0.85 & 0.86 \\
\hline Adj. R-squared & 0.77 & 0.71 & 0.76 & 0.81 \\
\hline$A R 1$ & 0.626 & 0.691 & 0.51 & 0.621 \\
\hline$A R 2$ & 0.617 & 0.521 & 0.581 & 0.612 \\
\hline Sargan/Hansen Test & 1.61 & 1.58 & 1.67 & 1.81 \\
\hline
\end{tabular}

Source: Author with Data from the World Bank and African Development Bank

The values in parentheses are Standard Deviation; ***, ** and * represent the significance of the error threshold of $1 \%, 5 \%$ and $10 \%$ respectively.

In fact, for the threshold of 5\%, if the p-value of the statistical AR1 or AR2 is less than 1.96, then we accept the hypothesis of independence of errors or the lack of autocorrelation of 
errors. At $1 \%$, if the statistical AR1 or AR2 is less than 2.536, the same conclusion is maintained. The p-values of the Sargan/Hansen test is widely used to accept the null hypothesis of the validity of instruments. Remember that the overall model is estimated by the Generalized Method of Moments (GMM).

The private investment (I), or FDI source of entrepreneurial process, is significant at $10 \%$. A percentage increase in the rate of investment leads to a $0.19 \%$ increase in economic growth. This low contribution of investment to economic growth is attributed to the hostile investment climate in the CEMAC sub-region. In fact, according to the Doing Business report of 2014, the countries of the CEMAC region appear towards the bottom of the chart of investment climate. In fact, of the 189 countries studied, three CEMAC countries come in the last position, that is, Congo in the $185^{\text {th }}$, Central Africa Republic in the $188^{\text {th }}$ and Chad in the $189^{\text {th }}$. This implies that investors encounter many difficulties in this sub-region. However, public investment $(\mathrm{G})$ is positively but insignificantly associated with economic growth; with government expenditure directed more towards social projects whose returns are felt only in the long-run.

The empirical result of the analysis of equations as contained in Tables above reinforces the hypothesis of the direct influence of capital market development and inflow of FDI on entrepreneurial process and economic growth in the CEMAC countries. More specifically, the results of the descriptive statistics show that the inflows of FDI to the CEMAC zone show a positive significance of FDI on the entrepreneurial process and on the economic growth in the CEMAC zone. An increase of FDI inflows contributes to increasing the creation of enterprises and to an increase in economic growth. Thus, despite this, FDI inflow in the region is fluctuating and the extent of the fluctuation has been noticeable. This is really a cause for concern for a region that yearns to achieve rapid economic development.

\section{Conclusion and Policy Implication}

This paper has analysed the relationship between capital market development and foreign direct investment on the entrepreneurial process and economic growth. The literature review conducted in this study established the link between capital market development, entrepreneurial process and the inflow of FDI in enhancing economic growth. This research has proposed to integrated entrepreneurial process in the comprehension of the entrepreneur from the perspective to understand the contribution of capital market development and foreign direct investment on economic growth. The capital market is found to be pivotal to financial deepening, which is capable of precipitating sustainable economic growth and entrepreneurial development; with capital market efficiency also found to be necessary to attract the inflow of FDI. If capital market and FDI provide knowledge and innovation technologies in CEMAC countries, they can stimulate entrepreneurial process and economic growth.

The affective and cognitive aspects are important in the entrepreneurial process dynamic framework. They contribute to change entrepreneurs' environment and positively affect 
capital market development. A fledgling capital market is largely inefficient, and highly susceptible to market failure, and capable of further enervating skittish foreign investors especially in the face of preponderant market failures in the developing world. The respect for the rule of law and the quality of legal framework, play very important roles in the development of the capital markets in the CEMAC sub-region as well as on the attractiveness of the sub-region to the inflow of FDI. Also, we suggest that, policy makers should increase an efficient capital market and instruments that focus on improving the attractiveness of the CEMAC economy to FDI. Such as improvement of the infrastructure, containment of inflation, fight against corruption and extend public investment by public private partnership in order to accelerate entrepreneurial process and economic growth. To that extent, concerted efforts like educational entrepreneurship are required to improve the legal framework in the CEMAC region.

The problems of terrorism and insecurity in the CEMAC countries contribute to give a bad illustration and limit expansion of capital market, FDI and local entrepreneurial process. It is important that all CEMAC governments take their responsibilities to resolve these situations in order to strengthen economic growth in this area.

In the light of the above results, the policy implications are as follow:

- The governments of CEMAC countries must create an enabling environment for domestic investors to invest in the capital market and removing all obstacles to local businesses.

- Government securities should be channelled to more productive sectors to complement those in the private sector.

- This study also recommends that the regulatory authorities of governments and financial markets develop and implement policies that will further stimulate the development of the CEMAC capital market so as to maintain its positive effect and attract the foreign portfolio.

- This study recommends that CEMAC countries place greater emphasis on the development of the financial sector, with particular emphasis on the development of capital markets to promote the entrepreneurial process and economic growth.

- The CEMAC countries must fight more against corruption in order to make foreign direct investment more attractive.

\section{References}

Adam, A. M., \& Tweneboah, G. (2009). Foreign Direct Investment and Stock Market Development: Ghana's Evidence. International Research Journal of Finance and Economics, 26, 178-185.

Adjasi, K. D., \& Biekpe, N. B. (2006). Stock Market Development and Economic Growth: The Case of Selected African Countries. African Development Review, 18(1), 144-161. https://doi.org/10.1111/j.1467-8268.2006.00136.x 
Africa Stock Exchange Association (2013). Comparative Highlights (Graphs)? Retrieved 2015/02/14 from http://www.africansea.org/ASEA/C

Ajagbawa, O. H. (2014). Entrepreneurship, Financial, and Economic Development: A Literary Review. IOSR Journal of Humanities and Social Science, 19(6), 85-118. https://doi.org/10.9790/0837-196485118

Akinmulegun S. O. (2018). Capital Market Development and Foreign Portfolio Investment Inflow in Nigeria (1985-2016). Advances in Economics and Business, 6(5), 299-307. https://doi.org/10.13189/aeb.2018.060503

Akyuz, Y. (1993). Financial Liberalization: The Key Issues in Finance and Real Economy, edited by Yilmaz Akyuz and Gunther Held. Santiago: United Nations University.

Allen, D. S., \& Ndikumana, L. (2000). Financial Intermediation and Economic Growth in Southern Africa. Journal of African Economies, 9(2), 132-160. https://doi.org/10.1093/jae/9.2.132

Arias, E.F., \& Hausman, R. (2001). Capital inflows and crisis: Does the Mix Matter? In: Braga de Macedo, Jorge, Iglesias, Enrique V. (Eds.), Foreign Direct Investment Versus Other Flows to Latin America. Paris: Inter-American Development Bank and OECD.

Baker, M., Foley, C. F., \& Wurgler, J. (2009). Multinationals as Arbitrageurs: The Effect of Stock Market Valuations on Foreign Direct Investment. The Review of Financial Studies, 22(1), 337-369. https://doi.org/10.1093/rfs/hhn027

Barna, F., \& Mura, P. (2010). Capital Market Development and Economic Growth: The Case of Romania. Annals of the University of Petrosani, Economics, 10(2), 31-42.

Bellon, B., \& Gouia, R. (1998). Investissements directs étrangers et développement industriel méditerranéen - Foreign Direct Investment and Industrial Development in the Mediterranean, Economica.

Benassy-Quere, A., Coupet, M., \& Mayer, T. (2007). Institutional Determinants of Foreign Direct Investment. The World Economy, 30(5), 764-782. https://doi.org/10.1111/j.1467-9701.2007.01022.x

Bencivenga, V., \& Smith, B. (1991). Financial Intermediation and Endogenous Growth. Review of Economic Studies, 58(2), 195-209. https://doi.org/10.2307/2297964

Binswanger, M. (1999). Stock Markets, Speculative Bubbles and Economic Growth. Cheltenham: Edward Elgar Publishing.

Bosworth, B. P., Collins, S. M., \& Reinhart, C. M. (1999). Capital Flows to Developing Economies: Implications for Saving and Investment. Brookings Papers on Economic Activity, 1, 143-180. https://doi.org/10.2307/2534664

Bygrave, W.D. (2004). The entrepreneurial Process. In W.D. Bygrave and A. Zacharakis (eds.), The portable MBA in entrepreneurship. Hoboken, N.J, Joohn Wiley and sons. 


\section{Macrothink}

Caves, R. E. (2007). Multinational Enterprise and Economic Analysis (3rd ed.). Boston, Cambridge University Press. https://doi.org/10.1017/CBO9780511619113

Chousa, J.P., Valdlamannati, K.C., \& Tamazian A. (2008). Does Growth and Quality of Markets Drive Foreign Capital? The Case of Cross-border Mergers and Acquisitions from leading Emerging Economies. William Davidson Institute Working Paper Number 911.

Corbett, J., \& Jenkinson, T. (1994). The Financing of Industry, 1970-1989: An International Comparison. Discussion Paper No. 948. London: Centre for Economic Policy Research.

Emmanuel A., \& King S. (2014). Effect of capital market development on economic growth in Ghana. European Scientific Journal, 10(7).

Filion, L. J. (1999). Diferenças entre sistemas gerenciais de empreendedores e operadores de pequenos negócios. Revista de Administração de Empresas, 39(4), 6-20. https://doi.org/10.1590/S0034-75901999000400002

Frott, K. A., \& Stein, J. C. (1991). Exchange Rates and Foreign Direct Investment: An Imperfect Capital Markets Approach. The Quarterly Journal of Economics, 106(4), 1191-1217. https://doi.org/10.2307/2937961

Gullapalli, R. (2013). Foreign capital and Firm Financial constraints - evidence from Two Systemic Liquid Crises. A paper Presented at the 2013 Annual Research Forum at George Mason University, Washington D.C; United States.

Haglund, D. (2008). Regulating FDI in Weak African States: A Case Study of Chinese Copper Mining in Zambia. The Journal of Modern African Studies, 46(4), 547-575. https://doi.org/10.1017/S0022278X08003480

Hebert, R.F., \& Link, A.N. (1989). In Search of the Meaning of Entrepreneurship. Small Business Economics, 1(1), 39-49. https://doi.org/10.1007/BF00389915

Ito, T. (1999). Capital Flows in Asia. NBER Working Paper Series No: 7134. https://doi.org/10.3386/w7134

Jeffus, W. M. (2004). FDI and Stock Market Development in Selected Latin American Countries. International Finance Review, 5, 35-44. https://doi.org/10.1016/S1569-3767(05)05003-X

Kersan-Skabic, I. (2004). Impact of FDI on Development of Small and Middle Entrepreneurship in Croatia. Zagreb International Review of Economics and Business, Conference issue, 35-49

King, R., \& Levine, R. (1993). Finance and Growth: Schumpeter Might Be Right. Quarterly Journal of Economics, 108(3), 717-37. https://doi.org/10.2307/2118406

Krueger, N.F. (2003). The Cognitive Psychology of Entrepreneurship, in Handbook of Entrepreneurship Research. Cur. Z.J. Acs, D.B. Audretsch, Manchester, Kluwer Academic Publisher, 105-140. 
Levine, R., \& Zervos, A. (1998). Stock Markets, Banks, and Economic Growth. American Economic Review, 88(3), 537-558.

Levine, R., \& Zervos, S. (1996). Stock markets development and long-run growth. The World Bank Economic Review, 10(2), 323-339. https://doi.org/10.1093/wber/10.2.323

Madura, J. (2001). Financial Markets and Institutions (5th Ed.). Cincinnati: South-western Publishers.

Maingy, C. (2004). L'impact des investissements directs étrangers sur les économies en développement. Région et Développement, 20, 65-89.

Mcclelland, D. (1965). Achievement motivation can be developed. Harvard Business Review, 43(6), 178-188.

Meyer, K. E. (2004). Perspectives on Multinational Enterprises in the Emerging Economies. Journal of International Business Studies, 35(4), 259-276. https://doi.org/10.1057/palgrave.jibs.8400084

Modigliani, F., Merton, H., \& Miller, M. H. (1958). The Cost of Capital, Corporation Finance and the Theory of Investment. The American Economic Review, 48(3), 261-297.

Naceur, S.B., Ghazouani, S., \& Omran, M. (2007). The determinants of stock market development in the Middle-Eastern and North African region. Journal of Managerial Finance, 33(7), 477-489. https://doi.org/10.1108/03074350710753753

Nassif, V.M.J., Ghobril, A.N., \& Da Silva, N.S. (2010). Understanding the Entrepreneurial Process: a Dynamic Approach. Brazilian Administration Review, 7(2), 213-226. https://doi.org/10.1590/S1807-76922010000200007

Oke, O.O.S., \& Jolaosho, M.O., (2014). Entrepreneuship contribution of Foreign Direct Investment: a reality of unfulfilled vision in Nigeria. International Journal of development and Sustainibility, 3(1), 184-195.

Onwuka, E., \& Chogozie, M.P. (2014). Foreign Direct Investment and Entrepreneuship Development in Nigeria (1990-2013). Research Journal's journal of entrepreneurship, 4(8), 234-242.

Ozaralli, N., \& Rivenburgh, N.K. (2016). Entrepreneurial intention: antecedents to entrepreneurial behavior in the U.S.A., \& Turkey. Journal of Global Entrepreneurship Research, 6, 1-32. https://doi.org/10.1186/s40497-016-0047-x

Philip, I., \& Obiajulu, O. (2017). The impact of financial development on foreign direct investment in Nigeria. Journal of Management and Social Sciences, 6(1).

Rousseau, P. L., \& Wachtel, P. (2000). Equity Markets and Growth: cross country evidence on timing and outcomes. Journal of Banking and Finance, 24, 1933-57. https://doi.org/10.1016/S0378-4266(99)00123-5

Rwelamira, P.G. (1993). The Critical Role of the African Stock Exchange in Mobilizing 
capital for African Private Enterprises, Nairobi, p. 3.

Singh, A. (1997). Stock Markets, Financial Liberalization and Economic Development. Economic Journal, 107(442), 771-782. http://dx.doi.org/10.1111/j.1468-0297.1997.tb00042.x

Stewart, W.H., \& Roth, P.L. (2001). Risk Propensity Differences Bbetween Entrepreneurs and Managers: A Meta-Analytic Review. Journal of Applied Psychology, 86, 145-153. https://doi.org/10.1037/0021-9010.86.1.145

Timmons, J. A. (1978). Characteritics and role demands of entrepreneurship. American Journal of Small Business, $3(1), \quad$ 5-17. https://doi.org/10.1177\%2F104225877800300102.

Vladimir, A. Tomislav, G., \& Irena, R. (2013).The Relationship between the Stock Market and Foreign Direct Investment in Croatia: Evidence from VAR and Cointegration Analysis. Journal of Financial Theory and Practice, 57(1), 109-126.

Vullo, C., Morando, M., \& Platania, S. (2017). Understanding the Entrepreneurial process: A Literature Review. Annali della facoltà di Scienze della formazionzner, Università degli studi di catania, 16, 89-102.

\section{Copyright Disclaimer}

Copyright for this article is retained by the author(s), with first publication rights granted to the journal.

This is an open-access article distributed under the terms and conditions of the Creative Commons Attribution license (http://creativecommons.org/licenses/by/3.0/). 